\title{
Prophylaxis against hepatitis A for travel
}

\author{
Phyllis Moore, Pippa Oakeshott, Jane Logan, Jennifer Law, D M Harris
}

\begin{abstract}
Objective-To develop a rational practice policy for prophylaxis against hepatitis $A$ for travellers to high risk areas.

Design-18 Month prospective study of consecutive patients who requested prophylaxis against hepatitis A.

Setting-Inner city general practice.

Subjects-104 Patients aged 15-61 (mean 30) assessed for risk factors for hepatitis $A$ and put into groups depending on predictions from the risk factors of their immunity.

Main outcome measures and results - All patients were screened for antibody to hepatitis A virus. Of 52 patients with no risk factors 47 had no antibody and were thus susceptible to hepatitis A. All 27 patients with major risk factors (having been brought up in an endemic area or with a history of jaundice) were immune. Of 25 patients with minor risk factors (a history of previous travel in high risk areas, drug abuse, having lived in a squat or travelled rough, or having lived with someone who had jaundice) 12 were immune ( $\mathbf{p}<\mathbf{0 . 0 0 1}, \chi^{2}$ test).

Conclusions-All travellers requesting prophylaxis against hepatitis $A$ should be assessed for risk factors for previous exposure to hepatitis $A$. Those with no risk factors could be immunised with human normal immunoglobulin without screening. The remainder should be tested for hepatitis $A$ antibody and those found to be susceptible should be immunised.
\end{abstract}

\section{Introduction}

Most young people in developed countries are susceptible to hepatitis A and need passive immunisation with human normal immunoglobulin when they travel to high risk areas such as the Indian subcontinent, Africa, and the Middle and Far East. However, some intending travellers already have antibodies to hepatitis $\mathrm{A}$ virus and are immune to the disease for life. If they are screened and shown to be immune they clearly do not need immunoglobulin or retesting for future trips. Similarly, if we could identify

BrMed f 1990;300:723-4

\section{Risk factors for exposure to hepatitis A}

\section{Major factors}

- Being born and brought up in areas where hepatitis $\mathrm{A}$ is endemic

- History of jaundice

Minor factors

- Having travelled in a high risk area

- Drug misuse

- Having lived in a squat or travelled rough

- Having lived with someone who had jaundice.

patients likely to be susceptible to hepatitis A who are making a single visit to an endemic area they could be given immunoglobulin without the expense and inconvenience of screening.

It is likely that few general practices bother with screening tests when travellers request prophylaxis against hepatitis A. We surveyed practices, mainly in the London area, that cared for a total of 115000 patients, and included three university departments of general practice. Only one practice (2300 patients) routinely offered travellers testing for hepatitis $\mathrm{A}$ antibody. The remainder immunised without screening unless there was a previous history of jaundice.

In 1987 Cossar and Reid suggested selective screening before immunising against hepatitis $\mathrm{A} .{ }^{\prime}$ We investigated their proposals in patients from a deprived area of central London to see whether we could develop a rational practice policy for prophylaxis against hepatitis A for travellers.

\section{Patients, methods, and results}

From March 1988 to October 1989 we studied prospectively 104 consecutive patients who requested prophylaxis against hepatitis A for travel to high risk areas. The age range was 15-61 years (mean 30 years). They were assessed for major risk factors for having been exposed to hepatitis A-namely, being born and brought up in areas where hepatitis $\mathrm{A}$ is endemic or having a history of jaundice-and for minor risk factors - namely, having previously travelled in a high risk area; drug abuse; having lived in a squat or travelled rough; or having lived with someone who had jaundice. (Drug abuse and living in a squat may be associated with social habits that put patients at risk of hepatitis A.')

Patients were grouped according to our predictions, from the risk factors, of their immune state. The 52 patients with no risk factors were put into one group, the 25 patients with minor risk factors were put into

\begin{tabular}{lrrrr} 
Antibody to HAV present (immune) & 5 & 12 & 27 & 44 \\
Not present (not immune) & 47 & 13 & & 60 \\
\hline Total & 52 & 25 & 27 & 104
\end{tabular}

$\mathrm{p}<0 \cdot 001, \gamma$ test 
another, and the 27 patients with major risk factors were put into a third.

Blood was taken and assayed for antibody to hepatitis A virus by a commercially available competitive enzyme linked immunoassay (ELISA) test (Havab, Abbott Laboratories). Those with antibody were told that they were immune to infectious hepatitis and would never need further screening or immunisation against hepatitis A. Those without antibody who returned as requested were immunised.

The table shows the immune state of patients in the three groups. Results were analysed with the $\chi^{2}$ test and found to be significant $(\mathrm{p}<0.001)$.

\section{Discussion}

Of 52 patients with no risk factors $47(90 \%)$ were susceptible to hepatitis $A$, whereas all 27 patients with major risk factors were immune. Those who were immune included two patients with a history of jaundice and 25 who had grown up in Africa or South Asia. Kudesia and Follett found that immigrants from Asia were "invariably immune" to hepatitis A, but their children born in Britain will not usually be immune and may be at particular risk if they go back to Asia on holiday without first being immunised.

Overall $42 \%$ (44 out of 104) of our patients had antibody to hepatitis A virus, but this included those brought up in an endemic area. Of 74 patients born in Britain, 16 (22\%) were immune. A survey of blood donors nearby in south London found that a third had the antibody, but their country of birth was not identified. Most were over 30 years old (prevalence of HAV antibody increases with age $\left.\mathrm{e}^{1-4}\right)$.
Human normal immunoglobulin can give $80-90 \%$ protection from hepatitis $\mathrm{A}$, which is a major hazard for Europeans in the tropics. In one series 12 of 19 expatriates working in India who did not receive adequate immunisation developed hepatitis A. The disease has an $0.6 \%$ mortality. Serious adverse effects from human normal immunoglobulin given as recommended are rare. The Committee on Safety of Medicines has received 12 reports of non-fatal anaphylaxis and one of death from suspected cerebral haemorrhage possibly associated with injection of human normal immunoglobulin (Committee on Safety of Medicines, personal communication).

Antibody testing costs from $£ 4$ to $£ 8$. An injection of human normal immunoglobulin costs £3-£9.' But our prime concern must be to ensure that none of our susceptible patients visits a high risk area without prophylaxis. We therefore recommend immunising all patients with no risk factors. The rest should be screened for antibody to hepatitis $A$ virus and those found to be susceptible should be immunised.

We thank Professor J E Banatvala and Drs A Tilzey and E C Poulton.

1 Cossar Y, Reid D. Not all travellers need immunoglobulin for hepatitis A Br.Med f 1987:294:1503.

2 Banatvala JE, Thorogood RJ. Hepatitis A antibodies in London blood donors, medical students and patients. Lancet 1980; i:595.

3 Kudesia $G$, Follett E. Not all travellers need immunoglobulin for hepatitis $A$ Br Med f 1987;295:118.

4 Parry J. Farrington C, Perry K, et al. Rational programme for screenin travellers for antibodies to hepatitis A virus. Lancet $1988 ; 1: 1447-9$. 5 Hill P. John T. Hepatitis prophylaxis for travellers. Lancet 1979;ii:300

(Accepted 24 fanuary 1990)

\section{Series in Death Education, Aging, and Health Care. Reference edition. "AIDS: Principles, Practices, and Politics." Ed I B Corless, M Pittman Lindeman. Consulting editor $\mathrm{H}$ Wass. (Pp xxix +583 ; £58.) New York: Hemisphere Publishing Corporation, 1989. ISBN 0-89116-716-1.}

Addiction

Alcoholism: Biomedical and Genetic Aspects. Ed H W Goedde, D P Agarwal. (Pp viii + 364; figs; \&33.51.) New York: Pergamon, 1989. ISBN 0-08035763-6.

Local Action on Alcohol Problems. Ed D Robinson, P Tether, J Teller. (Pp $\mathrm{x}+180 ; £ 4.95$ paperback.) London: Tavistock/Routledge, 1989. ISBN 0-415-00986-3.

\section{Anatomy}

Fundamental Anatomy for Operative General Surgery. S J Snooks, R F M Wood. (Pp viii +91 ; figs; $\$ 12$ paperback.) London: Springer, 1989. ISBN 3-540-19535-1.

\section{Back pain}

Back Pain: New Approaches to Rehabilitation and Education. Ed $M O$ Rolan, J R Jenner. (Pp xii +258 ; figs; £45.) Manchester: Manchester University Press, 1989. ISBN 0-7190 2789-6.

\section{Biology}

MBL Lectures in Biology. Vol 10. "Perspectives in Neural Systems and Behavior." Ed T J Carew, D B Kellev. (Pp xii + 276; figs; $\$ 38$ paperback. New York: Liss, 1989. Distributed by John Wiley and Sons. ISBN 0-84512211-8.

\section{Cardiology}

Cardiac Application of Digital Angio graphy. Ed A G Wasserman, A M Ross. (Pp xii +311 ; figs; \$53.) New York: Futura, 1989. ISBN 0-87993 332-1.

Commonsense Cardiology. G Strube, G Strube. (Pp vii +335 ; figs; $\{19.95$. Dordrecht: Kluwer Academic, 1988 Distributed by MTP Press. ISBN 0-7462-0078-1

Developments in Cardiovascular Medi cine. "Early Interventions in Acut Myocardial Infarction." Ed E Rapaport. (Pp xiv +266 ; figs; $£ 70.75$. Boston: Kluwer Academic, 1989. Distributed by MTP Press. ISBN 0-79230175-7.

Developments in Cardiovascular Medi cine. Vol 99. "Myocardial Contrast Two-Dimensional Echocardiography. Echocardiography," Ed S Meerbaum, R S Meltzer. (Pp xiv + 229; figs; $£ 58$. Dordrecht: Kluwer Academic, 198 Distributed by MTP Press. ISBN 0 7923-0205-2.

Fetal and Neonatal Cardiology. W A Long. (Pp xxv +863 ; figs and colour plates; £140.) Philadelphia: Saunders, 1990. Distributed by Harcourt Brace Jovanovich. ISBN 0-7216-1887-1

Child welfare

Child Sexual Abuse: Listening, Hearing and Validating the Experiences of Child ren. Ed H Blagg, J A Hughes, Wattam. (Pp x+190; figs; $\$ 19.9$ paperback.) Harlow: Longman, 1989. ISBN 0-582-05647-0.

Community medicin

Nol 20. "The Kidney in Diabetes

World Health Organisation Technical Report Series. No 780. "Strengthening the Performance of Communit Health Workers in Primary Health Care." Report of a WHO study group.
(Pp 46; Sw frs 6 paperback.) Geneva: World Health Organisation, 1989. ISBN 92-4-120780-9.

Dentistry

Clinical Techniques in Dentistry. "An Atlas of Glass-Ionomer Cements: a Clinician's Guide." G M Mount. (Pp iv+128; figs and colour plates; f29.95. London: Dunitz, 1989. ISBN 1-85317-006-2.

Clinical Techniques in Dentistry. "An Atlas of Minor Oral Surgery: Principles and Practice." D A McGowar. (Pp viii + 132; figs and colour plates; £29.95.) London: Dunitz, 1989. ISBN 0-948269-65-0.

Cross-Infection Control in General Dental Practice: a Practical Guide for the Whole Dental Team. D Croser, J Chipping. (Pp $x+118$; figs; $£ 18$ paperback.) London: Quintessence, 1989. ISBN 1-85097-010-6.

Periodontal Control: an Effective System for Diagnosis, Selection, Control and Treatment Planning in General Practice. A M Grace, F C Smales. (Pp 144; figs; £18 paperback.) London: Quintessence, 1989. ISBN 1-85097-009-2.

\section{Dermatology}

Clinical Handbooks Series. "Psoriasis and Eczema." Ed L Fry. (Pp vi + 202. figs; colour plates; 115 paperback.) Bristol: Clinical Press, 1989. ISBN 1-85+57-002-1.

Diabetes

Contemporary Issues in Nephrology. Vol 20. "The Kidney in Diabetes Mellitus." Volume and series eds B $M$ Brenner, J H Stein. (Pp x +234 ; figs 142.50.) New York: Churchill Livin stone, 1989. ISBN 0-4+3-08632-X. Diabetes Complicuting Pregnancy: the Goslin Clinc. Method. Ed J W' Hare. Pp xii +194 ; figs; £31.) New York: Liss, 1989. Distributed by John Wiley and Sons. ISBN 0-471-92387-7.

Disabled/handicapped peopl

Clinics in Developmental Medicine. No 106. "The Health and Social Needs of Young Adults with Physical Disabilities." A P Thomas, $1 \mathrm{COO}$ Bax, D P L Smyth. (Pp x+161; figs; £17.50.) London: Mackeith Press/Oxford: London: MacKeith Press/Oxford: Blackwell Scien

\section{Ear, nose, and throat}

Brainscan MCQs. "Ear, Nose and Throat Disease." K P Gibbin, P J Bradley. (Pp iv +156 ; $£ 11.95$ paperback.) London: Springer, 1989. ISBN 3-540-19559-9.

Hearing: Physiological Acoustics, Neural Coding, and Psychoacoustics. W L Gulick, G A Gescheider, R D Frisina. (Pp xi+409; figs; £35.) New York: Oxford University Press, 1989. ISBN 0-19-504307-3.

Environmental and public healt

Environmental Health Criteria. 79. "Dichlorvos." World Health Organisation. (Pp 157; Sw frs 16 paperback. Geneva: World Health Organisation, 1989. ISBN 92-4-154279-9.

Environmental Health Criteria. 81 "Vanadium." World Health Organisation. (Pp 170; Sw frs 19 paperback.) 1988. ISBN 92-4-154281-0.

Genetics

Frontiers in Molecular Biology. "Genes and Embryos." Ed D M Glover, B D Hames. (Pp xiv + 228; figs; £18 paperback.) Oxford: IRL Press at Oxford University Press, 1989. ISBN 0-19963029-1.

Geriatrics

Medicine in Old Age "Clinical Geriatric Cardiology" Ed R J Luch. (Pp xii+402; figs; f40.) Edinburgh: Churchill Livingstone, 1989. ISBN 0443-02872-9.

\section{Pharmacology}

Cellular Clocks. Vol 3. "Chronopharmacology: Cellular and Biochemical Interactions." Ed B Lemmer. Series editor L N Edmunds Jr. ( $P$ p xviii +720 ; figs; $\$ 180$.) New York: Dekker, 1989. ISBN 0-8247-8103-1.

\section{Miscellaneous}

David Kindersley: His Work and Workshop. With illustrations from the Workshop archives. M Shaw. (Pp 96; figs; $\{17.50$.) 1989. Cardozo Kindersley, 152 Victoria Road, Cambridge CB4 3DZ ISBN 0-9501946-3-8.

Frank Lake: the Man and His Work. J Peters. (Pp xv $+250 ; £ 12.95$ paperback.) London: Darton, Longman, and Todd, 1989. ISBN 0-232-51842-4. McBride: Behind the Myth. Bill Nicol. (Pp ix +214 ; paperback, price not Enterprises, 1989. ISBN 0-642-12992-

Material Properties and Stress Analysis in Biomechanics. Ed A L Yettram. (Pp $\mathrm{xi}+273$; figs; £50.) Manchester: Manchester University Press, 1989. ISBN 0-7190-2521-4.

The Tutorial Process. H S Barrows. (Pp iii +63 ; paperback, price not stated.) Springfield: Sourhern Illinois University School of Medicine, 1988. ISBN 0-931369-22-3.

An Unquiet Life: Memoirs of a Physician 